\title{
Marek Friedrich
}

\author{
Uniwersytet Gdański
}

\section{Motyw strachu w kampanii wyborczej na przykładzie działań marketingowych przed wyborami parlamentarnymi w Polsce w 2007 roku.}

Występowanie strachu, jako jednego z podstawowych stanów emocjonalnych, towarzyszy człowiekowi przez wszystkie okresy jego rozwoju. W toku dojrzewania i starzenia zmieniaja się bodźce wywołujące strach, przez co przybiera on odmienne formy i oddziałuje z różną intensywnością. Cechą wspólna, dla wszystkich postaci tego uczucia jest jego negatywne zabarwienie. Strach pojawia się zawsze w stanie poczucia zagrożenia, które wywoływane jest pewnością, bądź przypuszczeniem wystapienia sytuacji zagrażającej bezpieczeństwu. Z jednej strony strach może powodować mobilizację, chęć działania, z drugiej jednak, jego następstwem może być apatia i przygnębienie. Zdecydowanie jednak powszechniejszą reakcją na odczuwanie lęku jest aktywność1.

Zastraszaniem określić można świadome wzbudzanie strachu u innej osoby, przeważnie dla uzyskania partykularnych korzyści. Jest to działanie nastawione na uzyskanie zmian w postępowaniu, dzięki specyficznym skutkom wywoływanym przez strach2. Zdolność lęku do przynoszenia wymiernych efektów, sprawia, iż jest on powszechnie wykorzystywany jako narzędzie procesu manipulacji we wszystkich sferach aktywności człowieka. Przestrzenia, w której strach, jako instrument manipulacji stosuje się nader często, a jego rola wydaje się być znamienna, jest polityka.

Nie sposób dokonać oceny roli strachu odgrywanej w polityce jako jednoznacznie negatywnej, bądź pozytywnej. Na przestrzeni lat, lęk stanowił spoiwo

1 J. Pieter, Strach i odwaga, Warszawa 1971, s. 88.

2 Ibidem. 
łączące przywódcę z podwładnymi. Z drugiej jednak strony, lęk niejednokrotnie wyznaczał kierunki polityki zagranicznej, wymuszał chociażby budowanie fortyfikacji, czy konstruowanie strategii bezpieczeństwa, co w znakomitej większości przynosiło pozytywne rezultaty.

Współcześnie w polityce strach występuje zwykle w innych formach, choć oczywiście nadal istnieją aparaty państwowe, których funkcjonowanie w dużej mierze się na nim opiera. W państwach demokratycznych zjawisko lęku zostało niejako zhumanitaryzowane, po czym uległo zawłaszczeniu przez sferę marketingu politycznego. Na tej płaszczyźnie strach zaczał odgrywać niezwykle relewantna rolę, wynikająca z faktu, iż umiejętne wykorzystanie jego elementów może stać się katalizatorem zmian, czy motywem działania, wymuszając określone decyzje, które najdoskonalej przejawiają się przy wyborczej urnie.

Wykorzystanie zjawiska strachu przez sztaby wyborcze zakwalifikować należy do szerszej kategorii, jaką jest negatywna kampania wyborcza, która stanowi jedną z dominujących metod walki o głosy. Jej instrumentarium jest niezwykle bogate i właściwie wykorzystane, stanowić może groźną broń, będąca w stanie przechylić szalę wyborczego zwycięstwa.

Negatywna kampania wyborcza zakorzeniła się we współczesnym marketingu politycznym, stając się nieodzownym elementem poprzedzającym nieomal każdy akt wyborczy. Ten rodzaj politycznej agitacji, uznawany jest często za cechę charakterystyczną współczesnych kampanii wyborczych i jest z nimi utożsamiany, co budować może fałszywy obraz jego nowatorskości. Mimo obecnej intensyfikacji i brutalizacji działań składających się na kampanię negatywna, nie stanowi ona w życiu politycznym novum.

Jedne z pierwszych aktów, które zakwalifikować należy, jako negatywna kampanię wyborczą odnaleźć można w politycznej rywalizacji o urząd prezydenta Stanów Zjednoczonych w 1796 roku, która toczyła się pomiędzy Thomasem Jeffersonem a Johnem Adamsem. W rywalizacji tej pojawiły się materiały wyborcze w formie ulotek, które dyskredytowały politycznego przeciwnika. Przedstawiały one Adamsa, jako arystokratę i monarchistę o zapędach antydemokratycznych i dyktatorskich. Sztab federalistów odpowiedział na te ataki w formie materiałów charakteryzujących Jeffersona jako polityka na usługach Francji, troszczącego się jedynie o wyższe klasy społeczeństwa.

Znaczący wpływ na rozwój negatywnej kampanii wyborczej miało pojawienie i upowszechnienie się telewizji. Wynalazek ten, ze środka wyłącznie służącego 
rozrywce, częściowo odwracającego uwagę od zagadnień życia politycznego, stał się głównym dostarczycielem informacji o wydarzeniach politycznych. W wyniku tej transformacji, telewizja stała się idealną przestrzenią dla swoistej ekspansji negatywnej kampanii wyborczej. Już w pierwszych wyborach, w których posłużono się telewizja jako kanałem komunikacji z wyborcami pojawiły się negatywne reklamy polityczne. W 1952 roku podczas rywalizacji Dwighta D. Eisenhowera z Adlai'em Stevensonem, wyemitowana została seria reklam „Eisenhower odpowiada Ameryce”, która w sposób otwarty atakowała demokratów. Ataki te, co ważne, nie miały jeszcze charakteru czysto personalnego, gdyż nie padało w nich nazwisko Stevensona 3 .

Za moment przełomowy w historii negatywnej kampanii wyborczej uznać należy wyprodukowanie w 1964 roku, dla Lyndona Johnsona z Partii Demokratycznej, przez Tony'ego Schwatza, spotu zatytułowanego „Stokrotka” (Daisy Girl). Ta wyemitowana zaledwie jednokrotnie reklama, miała znaczacy, o ile nie największy wpływ na wynik wyborów prezydenckich w Stanach Zjednoczonych.

„Stokrotka” była wymierzona w Barry'ego Goldwatera z Partii Republikańskiej. Jej cel stanowiło utwierdzenie wyborców, że republikanin jest niebezpiecznym radykałem, mającym pozytywny stosunek do broni atomowej. Ukazywała ona kilkuletnią dziewczynkę, która odrywała płatki z tytułowego kwiatu, jednocześnie niezdarnie je licząc. W pewnym momencie głos dziewczynki został zastapiony niskim, męskim głosem, spoza kadru, prowadzącym typowe odliczanie przed wybuchem. Nagle widok kwiecistej łaki zastapiony zostaje obrazem wybuchu, w postaci tak zwanego „grzyba nuklearnego”. W trakcie eksplozji słychać głos Johnsona: „Wybór jest jasny: sprawić by na świecie wszystkie boże dzieci mogły żyć albo odejść w ciemność. Musimy się kochać wzajemnie, albo musimy umrzeć”. Zakończenie reklamy stanowią słowa narratora: „Głosuj na prezydenta Johnsona trzeciego listopada. Stawka jest zbyt wysoka by pozostać w domu"4. Nie sposób zauważyć, iż w spocie tym, w sposób doskonały wykorzystano grę trzema elementami. Trójelementowa koncepcja reklamy lękowej zakłada, iż należy zachować określony porzadek, poprzez podział spotu na trzy elementy:

1. prezentacja zagrożenia;

2. przyczyna zagrożenia;

3 Por. L.L. Kaid, A. Johnston, Negative versus positive television advertising in U.S. presidential campaigns, 1960-1988, "Journal of Communication", 41(3), 1991, s. 53-63.

${ }_{4}^{4}$ Por. E. Diamond, S. Bates, The Spot: The rise of political advertising on television, Cambridge 1992. 
3. sposób usunięcia zagrożenia 5 .

Niezwykle ważne jest nie tylko występowanie wszystkich tych elementów w reklamie, ale również zachowanie ich kolejności, która ma znaczący wpływ na odbiór przekazu.

„Stokrotka” stanowi doskonałe zobrazowanie trójelementowej koncepcji reklamy lękowej. Występują w niej nie tylko wszystkie trzy elementy charakterystyczne dla tego modelu, lecz również zachowana jest kolejność ich występowania. Początkowo w spocie tym przedstawione zostaje zagrożenie w postaci wybuchu ładunku nuklearnego. Następnie widzowi ukazuje się przyczyna zagrożenia, którą jest osoba Barry'ego Goldwatera, kandydata Republikanów na urząd prezydenta, słynącego z poparcia dla idei zbrojeń atomowych. Reklamę kończy prezentacja jedynego sposobu usunięcia zagrożenia, którym jest wybór Lyndona Johnsona na prezydenta.

Stany Zjednoczone uznać należy za miejsce narodzin i rozwoju negatywnej kampanii wyborczej, podobnie zresztą jak większości innych instrumentów współczesnego marketingu politycznego. Nie sa jednak Stany Zjednoczone jedynym państwem, w którego polityczny krajobraz wpisał się ten rodzaj politycznej agitacji. Doskonały obraz pozycji jaką w poszczególnych demokracjach zajmuja negatywne działania marketingowe przedstawiły badania przeprowadzone przez Christine Holtz- Bacha oraz Lynde Lee Kaid.

W swojej analizie porównawczej reklam politycznych, wykorzystywanych w krajach Europy Zachodniej, Stanach Zjednoczonych i Izraelu, Kaid i Holtz-Bacha stwierdziły, że podczas amerykańskich wyborów prezydenckich w 1992 roku (George Bush vs. Michael Dukakis), 37\% reklam koncentrowało się na ataku na przeciwnika. Zbliżony negatywizm cechował wybory parlamentarne w Niemczech w 1992 roku (32\%). Podczas wyborów prezydenckich we Francji w 1988 roku (Francois Mitterand vs. Jacques Chirac) oraz wyborów parlamentarnych w Wielkiej Brytanii w 1992 roku takich reklam było 25\%, natomiast w trakcie wyborów parlamentarnych we Włoszech w 1992 roku było ich 15\%. Największy odsetek reklam negatywnych (42\%), można było zaobserwować podczas wyborów parlamentarnych w Izraelu w 1992 roku6.

5 J.F. Tanner, J.B. Hunt, D.R. Eppright, The protection motivation model: A normative model of fear appeals, "Journal of Marketing" 55, 1991, s. 36- 45.

6 W. Cwalina, A. Falkowski, Marketing polityczny. Perspektywa psychologiczna, Gdańsk 2008, s. 495. 
Na gruncie współczesnego, wciąż młodego, marketingu politycznego w Polsce, elementy negatywnej kampanii wyborczej wykorzystywane są również często. Szczególną rolę w jej ramach odgrywa reklama lękowa, po którą sztaby wyborcze sięgają z coraz większą częstotliwością. Wynika to z faktu zauważalnej skuteczności zastraszania wyborców, będącej poniekąd efektem wyraźnej emocjonalności, częściowo ograniczającej wyborczy pragmatyzm Polaków. Jaskrawą wizualizację roli, jaką odgrywa instrument strachu w polskich kampaniach wyborczych, stanowi obraz wydarzeń poprzedzających wybory parlamentarne w 2007 roku.

Wybrany w 2005 roku Sejm, po licznych perturbacjach, zdecydował o skróceniu kadencji, latem 2007 roku. Decyzja o przedterminowych wyborach nie była dla większości ugrupowań zaskoczeniem, jednak nie pozwoliła na stworzenie długotrwałej i rozbudowanej kampanii wyborczej7. Zaistniała sytuacja stanowiła doskonałą płaszczyznę do rozbudzania i podsycania lęków społecznych, przez dwie główne siły polityczne konkurujące o zwycięstwo.

Strategia kampanii wyborczej prowadzonej przez Platformę Obywatelską w 2007 roku, opierała się na podkreślaniu, iż Prawo i Sprawiedliwość jest partią antysystemowa, mogącą stanowić zagrożenie dla demokracji w Polsce. Przekonanie to potwierdził podczas konwencji wyborczej PO w Krakowie popierajacy ta partię Władysław Bartoszewski, słowami: „Nie wierzcie frustratom czy dewiantom psychicznym, którzy swoje problemy psychiczne odreagowują na narodzie [...] Ja chcę umrzeć w kraju wolnym i stabilnym! Kategorycznie wypraszam sobie lżenie Polski przez niekompetentnych członków rządu, niekompetentnych dyplomatołków! [...] Polska potrzebuje rządu ludzi szanujących innych ludzi, a nie napęczniałych nienawiścia"”. Wydaje się, iż w słowach o śmierci w kraju wolnym i stabilnym, celowo wzbudzany jest lęk o utrzymanie standardów demokratycznego państwa prawa, w przypadku wygranej stronnictwa Jarosława Kaczyńskiego. Nakreślona przez Bartoszewskiego wizja zagrożeń czyhających na wolność, jako niekwestionowaną wartość dobitnie przemawiała do świadomości Polaków, która ukształtowana została poniekąd przez pamięć o najnowszej historii Polski, pełnej doświadczeń braku uznania dla idei wolności obywatelskiej.

7 M. Kanabaj, Ewolucja metod i narzędzi kampanii negatywnej w latach 2005- 2007 na wybranych przykładach, „Athenaeum. Political Science” 19, Toruń 2008, s.121.

8 M. Adamik-Szysiak, Telewizyjna reklama polityczna w Polsce w latach 2005- 2010, Lublin 2012, s. 71. 
Wzbudzenie atmosfery strachu, sztab Platformy próbował osiagnać również poprzez emisję telewizyjnych spotów, nasyconych negatywnymi emocjami oraz pesymizmem. Najczęściej emitowanym telewizyjnym materiałem wyborczym był tak zwany „krótki film o życiu”, w którego pierwszej części usłyszeć można mająca wzbudzić niepokój muzykę oraz ponury głos lektora, mówiacego: „Przez ostatnie dwa lata sytuacja budżetówki drastycznie się pogorszyła. Lekarze i pielęgniarki, pracują na kilku etatach. Nauczycielom nie starcza do pierwszego. Pacjentów nie stać na lekarstwa. Szpitale bankrutują. W tym roku oddano do użytku niecałe 8 kilometrów autostrad. W ciagu ostatnich dwóch lat na drogach zginęło prawie 11 tysięcy ludzi. Przez ostatnie dwa lata z kraju wyjechało za chlebem prawie dwa miliony Polaków". Nastrój dramatyzmu potęgowany był przez będące tłem dla tych słów sceny między innymi budzącej się o 4:38 matki ze smutkiem opuszczającej swoje dziecko, cierpiącej pacjentki leżącej na szpitalnym korytarzu, czy przydrożnego krzyża. Wszystkie obrazy ukazane są wyłącznie w ciemnych, szarych barwach, stanowiących dopełnienie dramaturgii, rodzącego poczucie zagrożenia i strachu. Druga część spotu zbudowana jest na zasadzie kontrastu do pierwszej. Następuje zmiana kolorystyki na wielobarwną i ciepłą, muzyka z ponurej staje się żywiołowa, a zamiast przerażającego głosu lektora słychać przyjazny głos lidera PO, mówiącego: "Już wkrótce Polacy będą wracać z emigracji, bo praca tu będzie się opłacać. Będą nas leczyć dobrze zarabiający lekarze i pielęgniarki. Dobrze zarabiający nauczyciele będą uczyć nasze dzieci. a dobrze zarabiający policjanci będą dbać o nasze bezpieczeństwo. Przy bezpiecznych drogach wyrosną nowoczesne stadiony i pływalnie. Czy to możliwe? Skoro udało się w Irlandii, dlaczego ma nie udać się w Polsce? Przecież Polacy to wielki i mądry naród. Polskę też stać na swój cud gospodarczy. Musimy tylko wygrać te wybory."

Spot ten nie ma typowego trójelementowego układu, charakterystycznego dla klasycznego modelu reklamy lękowej. Pojawia się w nim raczej zestawienie dwóch rzeczywistości - obecnej i przyszłej, której wystapienie uwarunkowane jest podjęciem odpowiedniej decyzji wyborczej. Nie występuje tu typowe ukazanie, tak zwanego „czarnego scenariusza”, mającego wzbudzić strach u odbiorcy. Zamiast lękogennej wizji przyszłości pojawia się nasycona negatywnymi emocjami, wizja stanu teraźniejszego, którego perspektywa trwania może budzić silne obawy.

W podobny klimat wpisywały się również elementy kampanii zewnętrznej autorstwa sztabu PO. Istotną częścią tej kampanii były czarno-białe billboardy zawierające w górnej - czarnej części słowa „zasady PiS”, pod którymi widniały nega- 
tywne sformułowania, takie jak „oszczerstwa”, „pogarda”, „agresja”, dolna czarna sekcja zawierała napis: „Rządzi PiS a Polakom wstyd”. Formy te stanowiły swoiste uzupełnienie spotów wyborczych, nie będąc jednak tak wymownymi i silnie oddziaływującymi na wyobraźnię, jak materiały telewizyjne.

Wykorzystanie instrumentu strachu przez sztabowców PO przybrało formułę, którą najlapidarniej określić można jako „zastraszanie PiS-em”, ukazanym, jako partia antysystemowa i poniekąd niedemokratyczna, będąca zagrożeniem dla fundamentów tworzących w Polsce państwo prawa. Formuła ta, patrząc przez pryzmat wyników wyborów, wydaje się być niezwykle skuteczna, o czym dodatkowo świadczy fakt, iż stronnictwo Donalda Tuska wielokrotnie odwoływało się do niej w przyszłości. Zarówno w wyborach w 2007 roku, jak i w kolejnych, znacząca część głosów oddanych na Platformę Obywatelską stanowiły głosy, które nazwać można "głosami anty-PiS”. Ich oddanie nie było efektem realnego poparcia dla PO, lecz stanowiło wynik niechęci wobec partii Kaczyńskiego oraz strachu przed jej powrotem do władzy, które to emocje częściowo były rezultatem skutecznego wzbudzania i podsycania lęku przez sztabowców Platformy.

We wzbudzaniu atmosfery strachu, szansę na wyborcze zwycięstwo upatrywał również główny rywal polityczny Platformy Obywatelskiej, Prawo i Sprawiedliwość. W swojej koncepcji, sztabowcy tej partii postanowili wykorzystać zapowiedzi zmian w służbie zdrowia autorstwa Platformy, wiążące się częściowo z prywatyzacją szpitali. Zapowiedzi te zbiegły się w czasie z aresztowaniem przez Centralne Biuro Antykorupcyjne, pod zarzutem korupcji, posłanki PO Beaty Sawickiej, która między innymi powoływała się na swoje wpływy przy prywatyzacji szpitali

Głównym narzędziem do wykorzystania powstałej sytuacji było przygotowanie spotu pt. „prywatyzacja”, który emitowany był wyłącznie w dwóch ostatnich dniach kampanii, z wyjątkowo dużą częstotliwością. W materiale tym, roztaczała się fatalna wizja działania sprywatyzowanej służby zdrowia. Jego forma była niezwykle prosta. Widzowi ukazywała się czarna plansza z napisem: „propozycja PO - prywatyzacja szpitali”, któremu towarzyszyła wizualizacja. Plansza ta stanowiła tło dla najistotniejszego w tym spocie dialogu:

- Halo, szpital?

- Tak, słucham.

- Proszę przysłać karetkę do mojego męża!

- Proszę numer ubezpieczenia i karty kredytowej.

- Nie mam teraz pieniędzy, nie mam karty, proszę przysłać karetkę! 
- Karetkę wyślemy tylko po dokonaniu płatności. Dziękuję, do widzenia.

Ostatnim słowom dialogu towarzyszył widok ciagłej linii odczytu EKG, któremu towarzyszył charakterystyczny nieprzerywany sygnał, będący oznaką śmierci pacjenta, po którym pojawił się głos lektora, mówiącego: „Prywatyzacja szpitali to chęć zysku stawiana wyżej niż dobro pacjenta. Prywatyzacja szpitali to kolejne ogniwo korupcji”. Następnie pojawiała się część spotu, którą określić można mianem pozytywnej. Jej pierwszy plan stanowiła postać Zbigniewa Religi, wypowiadającego słowa: „Nie zgodzimy się na prywatyzację szpitali. W każdym kraju europejskim służba zdrowia opiera się na szpitalach publicznych". Słowom tym towarzyszy zupełnie inna niż na początku materiału muzyka, mająca budzić zaufanie i spotęgować optymistyczny wydźwięk zakończenia reklamy.

Materiał ten w wymiarze zarówno wizualnym, jak i słownym, miał budzić lęk. Zwłaszcza wykorzystany w warstwie dźwiękowej i obrazowej, symbol odczytu EKG mógł przemawiać do wyobraźni odbiorców, podsycając w nich niepokój o przyszłość polskiej służby zdrowia, a tym samym poniekąd o zdrowie, a nawet życie, swoje i swoich bliskich. Dramaturgię przekazu zwiększał fakt, iż sytuacja opieki zdrowotnej w Polsce od lat była sferą trosk i niepokojów społecznych, przez co trafiał on na podatny grunt.

W spocie tym odnaleźć można wszystkie elementy klasycznej koncepcji trójelementowej reklamy wyborczej autorstwa Tannera, Hunta i Epprighta. Występuje w nim zarówno prezentacja zagrożenia, jakim jest perspektywa prywatyzacji służby zdrowia, jak również wskazanie na przyczynę zagrożenia, którą stanowią propozycje zmian w systemie służby zdrowia autorstwa Platformy Obywatelskiej. Całości dopełnia wskazanie sposobu usunięcia zagrożenia, który stanowi oddanie głosu w wyborach na Prawo i Sprawiedliwość.

Nie sposób jednoznacznie ocenić skuteczności kampanii zastraszania, autorstwa Prawa i Sprawiedliwości. Wydaje się, iż jej wymowność oraz fakt, że trafiła na podatny grunt sprawiły, iż prywatyzacja szpitali była jednym z głównych tematów kampanii w 2007 roku, przynosząc obozowi PiS- u efekt, w postaci oddanych na niego głosów, będących rezultatem skutecznego straszenia prywatyzacją placówek opieki medycznej. Patrząc jednak przez pryzmat rezultatu wyborczego strategia partii Jarosława Kaczyńskiego nie była wystarczająco efektywna, gdyż nie przyniosła jej zwycięstwa w wyborach roku 2007.

Strach, będący jedną z podstawowych ludzkich cech pierwotnych może przybierać odmienne formy, przez co jego oddziaływanie jest zróżnicowane. Zdol- 
ność tej emocji do silnego oddziaływania na ludzkie zachowania sprawia, iż jest ona często wykorzystywana w sferze manipulacji. Szczególną rolę zaś, lęk odgrywa w działaniach o charakterze politycznym, zwłaszcza, jako nieodzowny element marketingu politycznego, w którym umiejętne gospodarowanie strachem stanowić może źródło wyborczego sukcesu. Na polskiej scenie politycznej trudno doszukać się kampanii wyborczej, w której elementy lęku nie byłyby wykorzystane. Wydaje się jednak, iż atmosfera kampanii roku 2007, nasycona była strachem w stopniu szczególnym, co miało znaczący wpływ na ostateczne wyniki wyborów. 